\title{
Aftermath of induced inflammation: acute periaortitis due to nivolumab therapy
}

\author{
Ashish K Roy, Harshavardhan R Tathireddy, Moni Roy
}

OSF Saint Francis Medical Center, Peoria, Illinois, USA

\section{Correspondence to} Dr Ashish K Roy, aashishkumarroy@gmail.com

AKR and MR contributed equally.

Accepted 7 September 2017

\section{DESCRIPTION}

A 57-year-old man with medical history of left upper lobe metastatic squamous cell carcinoma of lung and seizures due to brain metastasis was admitted with acute-onset low back pain. Patient also had a known history of infrarenal aortic and left common iliac artery aneurysm stable on regular surveillance CT over the past 3 years with the most recent CT scan 1 month prior to presentation showing no signs of inflammation around the infrarenal aneurysmal aorta as seen in figure 1. Positron emission tomography 1 year prior to presentation did not show signs of inflammation in the region of aortic aneurysm as shown in figure 2. For his metastatic lung cancer, he was initially started on carboplatin and gemcitabine therapy but unfortunately had progression of cancer in left lung on the regimen. Subsequently, he was placed on nivolumab therapy. After being on the medication for 9 months, patient presented with acute low back pain that started about 1 hour after completion of nivolumab infusion. Pain was described as sharp, 10/10 in intensity, radiating across the back, no associated nausea, vomiting, diaphoresis, fever, chills or urinary symptoms. The pain resolved after administration of methylprednisolone sodium succinate injection $60 \mathrm{mg}$ once with no recurrence of symptoms during hospital stay and on 1-month follow-up. CT showed stable diameter of infrarenal abdominal aortic aneurysm and unchanged intimal flap involving the left iliac artery without extension into the distal aorta consistent with chronic

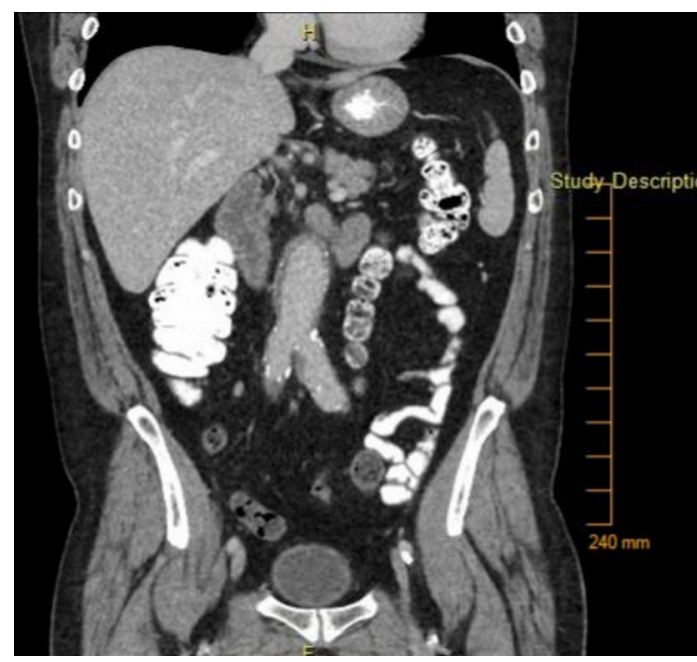

Figure 1 Coronal CT image showing fusiform dilation of infrarenal aorta 1 month prior to presentation with back pain.

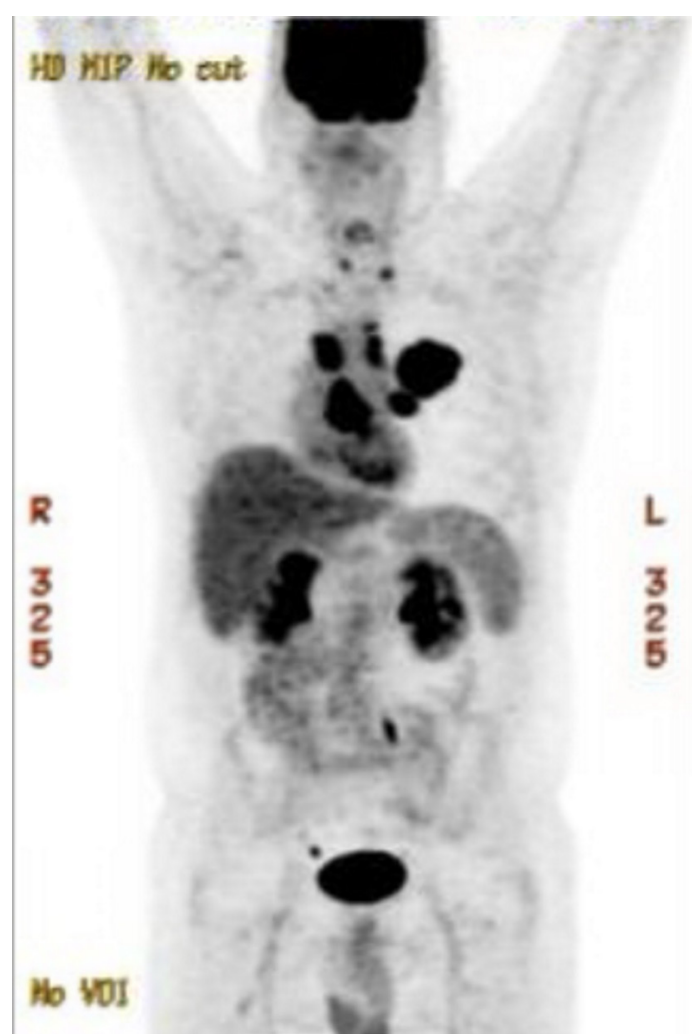

Figure 2 Positron emission tomographic image done 1 year prior to presentation showing left upper lobe malignancy with metastatic adenopathy and $\mathrm{T} 1$ vertebra skeletal metastasis. No increased uptake noted around infrarenal aortic aneurysm.

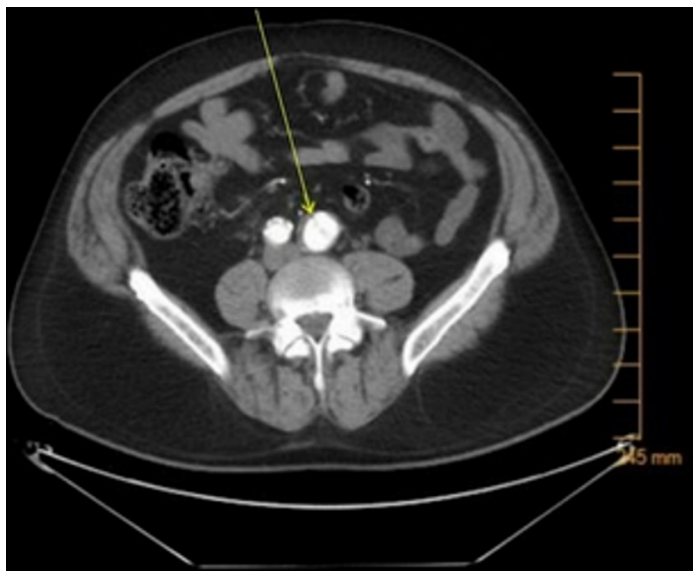

Figure 3 Axial CT image showing intimal flap in the left common iliac artery (downward arrow). 


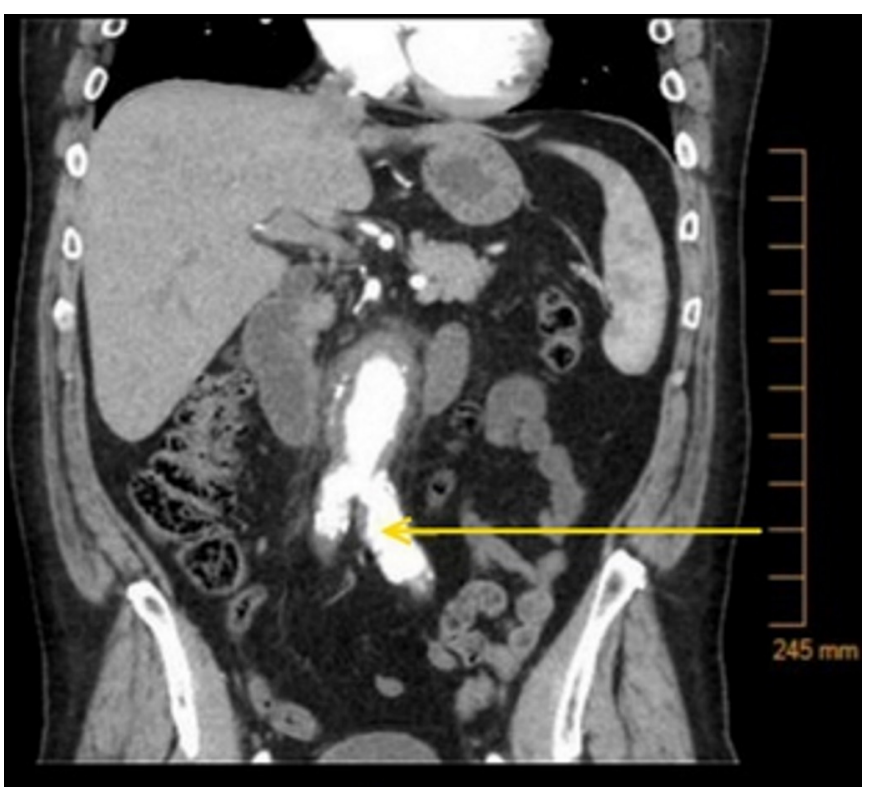

Figure 4 Coronal CT image showing linear filling defect within left common iliac artery aneurysm consistent with a chronic intimal flap (left arrow) and fusiform dilation of infrarenal abdominal aorta.

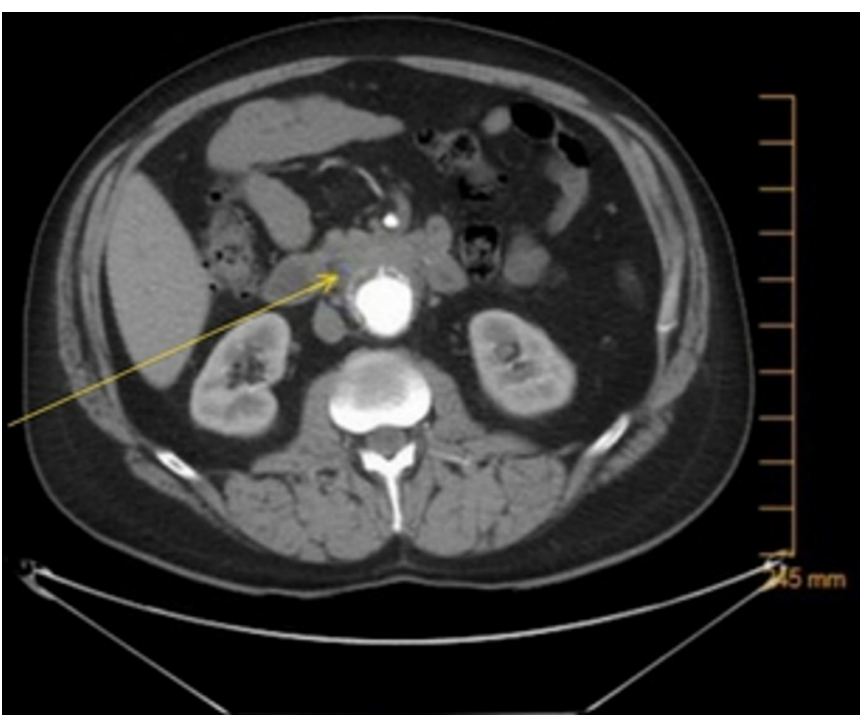

Figure 5 Axial CT image showing periaortic soft tissue thickening involving the distal infrarenal abdominal aorta (right arrow). dissection as shown in figures 3 and 4 and these changes were noted on prior CT scan as well. A new finding on the CT was increase in periaortic soft tissue thickening involving distal infrarenal abdominal aorta consistent with acute periaortitis as shown in figure 5. Laboratory studies to rule out other possible infectious and autoimmune causes of acute periaortitis were obtained as shown in table 1 . Infectious aetiology was ruled out and patient was started on oral prednisone taper for 4 weeks. The acute onset of back pain, starting immediately after nivolumab infusion, elevated inflammatory markers and resolution of pain after administration of high-dose steroid was consistent acute inflammatory process most likely due to nivolumab therapy. An aortic biopsy in this setting of acute inflammation was not undertaken due to the risks of procedure. A decision was made to treat conservatively with steroid taper and holding nivolumab infusion after discussion with oncologist and rheumatologist. Repeat CT scan done 8 weeks after stopping nivolumab therapy showed interval decrease in soft tissue thickening along the anterior aspect of abdominal aortic aneurysm as shown in figure 6 .

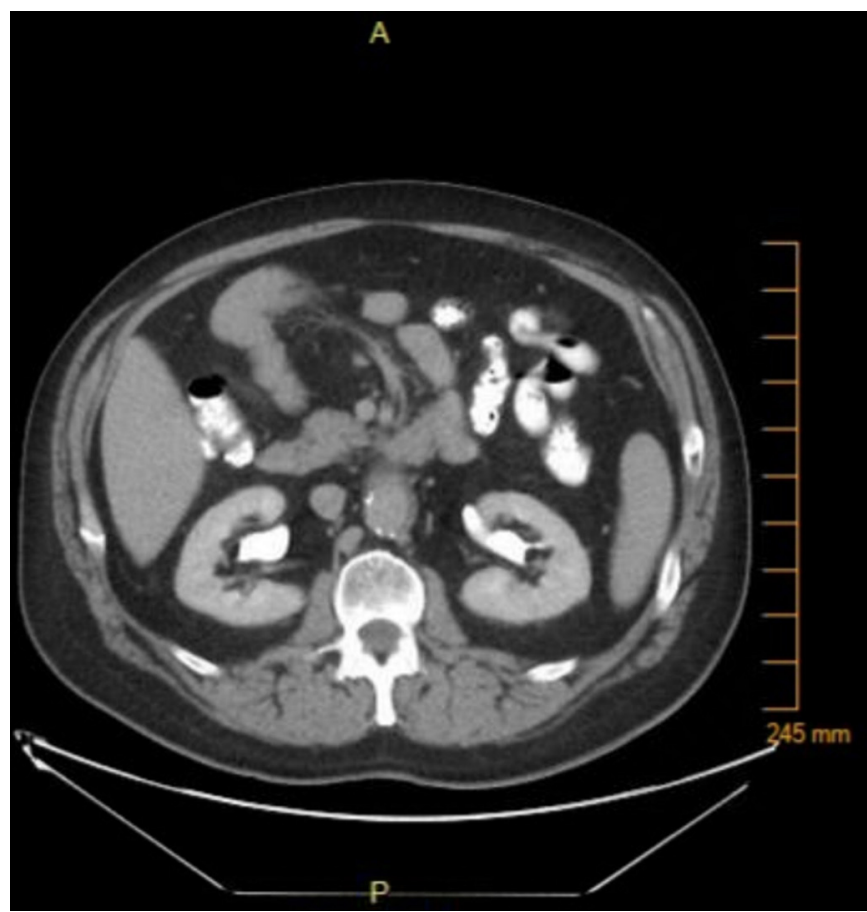

Figure 6 Axial CT image showing interval decrease in soft tissue thickening along the anterior aspect of abdominal aortic aneurysm.

\begin{tabular}{|c|c|c|}
\hline Test & Normal range & Result \\
\hline Erythrocyte sedimentation rate & $0-15 \mathrm{~mm} /$ hour & $31 \mathrm{~mm} /$ hour \\
\hline C-reactive protein & $<0.50 \mathrm{mg} / \mathrm{dL}$ & $4.43 \mathrm{mg} / \mathrm{dL}$ \\
\hline Antinuclear antibody screen & Negative & Negative \\
\hline Antineutrophilic cytoplasmic antibodies & $<1: 20$ titre & $<1: 20$ \\
\hline Blood culture (bacterial) & Negative & Negative after 5 days \\
\hline Blood culture (fungus) & Negative & Negative after 1 week \\
\hline Rapid plasma reagin (RPR) screen & Non-reactive & Non-reactive \\
\hline Hepatitis A IgM antibody & Non-detected & Non-detected \\
\hline Hepatitis B core antibody & Non-detected & Non-detected \\
\hline Hepatitis B surface antigen & Non-detected & Non-detected \\
\hline Hepatitis C antibody & $<0.79$ signal/cut-off ratio & 0.54 \\
\hline HIV 1 and 2 antibody antigen screen & Non-detected & Non-detected \\
\hline
\end{tabular}


Nivolumab is human IgG4 anti-PD1 immune checkpoint antibody that has recently emerged as a therapy for metastatic non-small cell lung cancer. ${ }^{12}$ This being a newer class of medication the side effect profile is currently under study. The mode of action (MOA) is activation of immune response against cancer cells and the MOA for this drug class is the best explanation for reported side effects of immune-mediated pneumonitis, hepatitis and gastritis to name a few. El-Refai et al recently reported that more than $25 \%$ of patients with lung and renal cancer had a coexisting autoimmune condition that is at risk of worsening with immune checkpoint inhibition. ${ }^{3}$ In our patient, no history of autoimmune disorder was present. Our patient did have a known history of atherosclerotic aneurysm and chronic dissection of infrarenal aortic segment, which in itself is a result of

\section{Learning points}

Nivolumab is a human IgG4 anti-PD1 immune check point antibody that acts by activation of immune response against cancer cells.

- Acute periaortitis is a possible side effect of nivolumab in patients with underlying chronic atherosclerotic aneurysm and dissection. chronic inflammation in the arterial wall with formation of atherosclerotic plaque. CT scan of abdomen 1 month prior to onset of symptoms did not show significant fat stranding around the aneurysmal aorta. It is very likely that the immune checkpoint inhibitor leads to a state of acute or chronic inflammation, leading to periaortitis. The safety of this class of medication is still to be studied and the risk versus benefit of the medication has to be assessed on case to case basis.

Contributors AKR and MR wrote the initial manuscript and performed literature review. AKR, MR and HRT performed the final manuscript designing. All authors read and approved the manuscript prior to submission.

Competing interests None declared.

Patient consent Obtained.

Provenance and peer review Not commissioned; externally peer reviewed.

(c) BMJ Publishing Group Ltd (unless otherwise stated in the text of the article) 2017. All rights reserved. No commercial use is permitted unless otherwise expressly granted.

\section{REFERENCES}

1 Borghaei H, Paz-Ares L, Horn L, et al. Nivolumab versus docetaxel in advanced nonsquamous non-small-cell lung cancer. N Engl J Med 2015;373:1627-39.

2 Brahmer J, Reckamp KL, Baas $\mathrm{P}$, et al. Nivolumab versus docetaxel in advanced squamous-cell non-small-cell lung cancer. N Engl J Med 2015;373:123-35.

3 El-Refai SM, Brown JD, Black EP, et al. Immune checkpoint inhibition and the prevalence of autoimmune disorders among patients with lung and renal cancer. Cancer Inform 2017; 16:1176935117712520.

Copyright 2017 BMJ Publishing Group. All rights reserved. For permission to reuse any of this content visit http://group.bmj.com/group/rights-licensing/permissions.

BMJ Case Report Fellows may re-use this article for personal use and teaching without any further permission.

Become a Fellow of BMJ Case Reports today and you can:

- Submit as many cases as you like

- Enjoy fast sympathetic peer review and rapid publication of accepted articles

- Access all the published articles

Re-use any of the published material for personal use and teaching without further permission

For information on Institutional Fellowships contact consortiasales@bmjgroup.com

Visit casereports.bmj.com for more articles like this and to become a Fellow 